\title{
Strength Behavior of Geopolymer Based SIFCON with Different Fibers
}

\author{
Mukhallad M. M. Al-Mashhadani ${ }^{1 *}$ \\ 1* Department of Civil Engineeirng, Istanbul Gelisim University, Turkey, (ORCID: 0000-0002-1646-5879), mashhadani@gelisim.edu.tr
}

(1st International Conference on Applied Engineering and Natural Sciences ICAENS 2021, November 1-3, 2021)

(DOI: 10.31590/ejosat.)

ATIF/REFERENCE: Al-Mashhadani, M. M. M. (2021). Strength Behavior of Geopolymer Based SIFCON with Different Fibers. European Journal of Science and Technology, (28), 1342-1347.

\begin{abstract}
Fabricating cementitious composites with sustainable materials represents an essential aspect in the recent developments in the construction section. On the other hand, using fibers within the binding matrix to enhance its strength properties is a familiar application and holds significant importance to the research community. In this investigation, the Geopolymer matrix which is based on silica fume (micro silica) and blast furnace slag (GGBS) was reinforced with five different fiber types to form slurry fiber reinforced concrete (SIFCON). Hook-ended steel, crimped steel, elastoplastic, macro twisted, and macro nylon fibers were used, the results revealed the fact that steel-based specimens generally yielded better results when compared to specimens reinforced with other fiber types. Normal condition results of hook-ended and crimped fiber-based specimens yielded an increment of more than 10\% in both compressive and flexural strength tests while their elevated temperature results showed strength loss rates less than specimens with other fiber types. Also, with acceptable performance in both conditions, macro twisted fibers can be considered as potential fibers for geopolymer based SIFCON.
\end{abstract}

Keywords: Geopolymer, SIFCON, Crimped fibers, Elastoplastic, Macro twisted.

\section{Farklı Lifli Geopolimer Esaslı SIFCON Betonların Dayanım Davranışı}

Öz

Sürdürülebilir malzemelerle çimentolu kompozitlerin üretilmesi, inşaat bölümündeki son gelişmelerde önemli bir yönü temsil ediyor. Öte yandan, mukavemet özelliklerini geliştirmek için bağlayıcı matris içinde liflerin kullanılması tanıdık bir uygulamadır ve araştırma topluluğu için önemli bir öneme sahiptir. Bu araştırmada, silis dumanı (mikro silika) ve yüksek fırın cürufu (GGBS) esaslı Geopolimer matris, bulamaç elyaf takviyeli beton (SIFCON) oluşturmak için beş farklı elyaf türü ile güçlendirildi. Kanca uçlu çelik, kıvrımlı çelik, elastoplastik, makro bükümlü ve makro naylon lifler kullanılmış, sonuçlar çelik esaslı numunelerin diğer lif türleri ile takviye edilmiş numunelere göre genel olarak daha iyi sonuç verdiğini ortaya koymuştur. Kanca uçlu ve kıvrımlı elyaf esaslı numunelerin normal durum sonuçları, hem basınç hem de eğilme mukavemeti testlerinde \%10'dan fazla bir artış sağlarken, yüksek sıcaklık sonuçları diğer elyaf türlerine sahip numunelere göre daha az mukavemet kaybı oranları göstermiştir. Ayrıca, her iki koşulda da kabul edilebilir bir performansla makro bükümlü lifler, jeopolimer bazlı SIFCON için potansiyel lifler olarak kabul edilebilir.

Anahtar Kelimeler: Geopolimer, SIFCON, kıvrımlı lifler, Elastoplastik lifler, Makro lifler.

\section{Introduction}

The construction sector around the world witnesses an increase in terms of using major resources such as water and natural rocks. Within this scope, the production of cementitious binding materials represents a major issue because of the greenhouse gas emissions. $\mathrm{CO} 2$ emissions from cement production form approximately $7 \%$ of the total $\mathrm{CO} 2$ emissions $[1,2]$.
The aforementioned facts led so many researchers to develop new technologies and experimental attempts to fabricate alternative binders that are based on environmentally friendly materials. Within this field, many investigations were conducted to partially or fully replace ordinary Portland cement (OPC) [3]. Geopolymer technology, which was firstly developed by Prof. Joseph Davidovits, holds significant importance in terms of wastes utilization and fabricating non-cementitious binders which are based on wastes and by-product materials $[4,5]$.

*Corresponding Author: mashhadani@gelisim.edu.tr 
On the other hand, the flexural properties of cement-based composites always show weakness in tension zones due to the brittleness of cement composites [6]. In this concern, using fibers to enhance the flexural behavior is one of the familiar practices because of the high tensile strength of fibers $[7,8]$.

In some experimental applications, the main goal was to gain a flexural strength that is close to the compressive strength. Slurry Fiber Reinforced Concrete (SIFCON) is one of the successful approaches in this field and is found in a wide range of applications that require high flexural strength [9-11].

Many research attempts focused on developing Geopolymer composites and SIFCON separately, but there is a lack of studying their behavior together, thus, the main objective of this investigation will be to evaluate the performance of geopolymer based SIFCON composites. Compressive and flexural strength properties of geopolymer-based SIFCON specimens fabricated with five various fibers (steel-hook ended, steel-crimped, elastoplastic, polyamide and nylon) were determined in normal condition and being subjected to elevated temperatures (250 and 500) ${ }^{\circ} \mathrm{C}$.

\section{Material and Method}

The details of used materials, the mixing proportions, and the applied standards and test procedures were explained in this section as follows:

\subsection{Materials}

The main binding materials used in this study were silica fume (micro-silica) which was provided from Eti Antalya Electrometallurgy Inc. (Kepez-Antalya/Turkey) and ground granulated blast furnace slag (GGBS) which was provided from Bolu Cement Company (Bolu/Turkey), the chemical compositions of silica fume and slag are listed in table 1. Sodium silicate and sodium hydroxide were used as activators; their details are given in tables 2 and 3. Fine river sand which is correspondent to BS EN 196-1 [12] and Rilem Cembureau standard was used in this study. the Sieve analysis of river sand is shown in figure 2.

Five different fibers were in this study and their properties are given in table 4, Samples of the used fibers are shown in figure 3.

\section{a)}

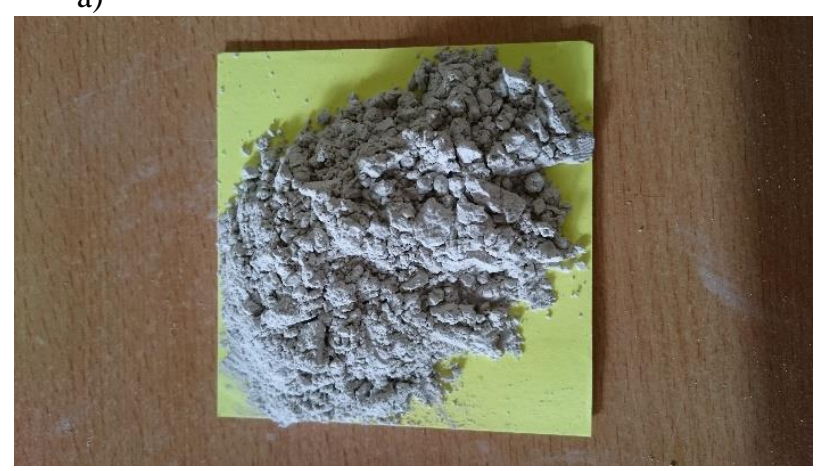

b)

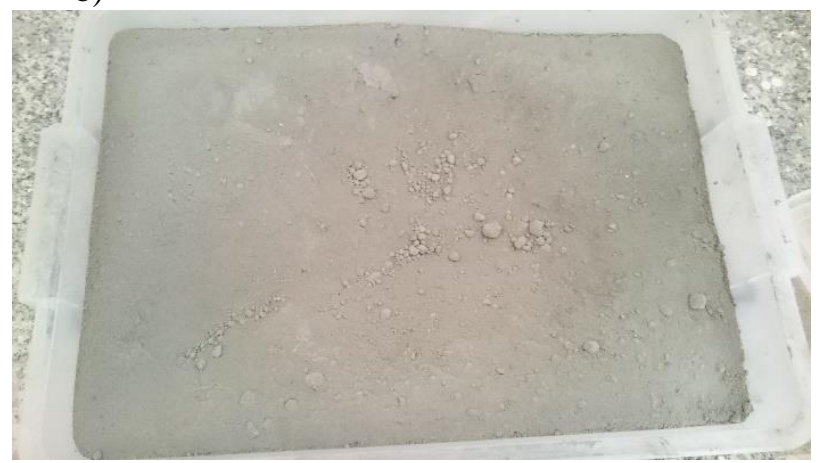

Fig. 1 A Sample of a) GGBS and b) silica fume

Table 1 Chemical composition of silica fume and GGBS

\begin{tabular}{|l|c|c|}
\hline \multicolumn{1}{|c|}{$\begin{array}{c}\text { Chemical } \\
\text { Analysis }\end{array}$} & GGBS & Silica Fume \\
\hline $\mathrm{SiO}_{2}$ & 40.55 & 91.57 \\
\hline $\mathrm{Al}_{2} \mathrm{O}_{3}$ & 12.83 & 0.38 \\
\hline $\mathrm{Fe}_{2} \mathrm{O}_{3}$ & 1.10 & 0.15 \\
\hline $\mathrm{TiO}_{2}$ & 0.75 & - \\
\hline $\mathrm{CaO}$ & 35.58 & 0.32 \\
\hline $\mathrm{MgO}$ & 5.87 & 4.05 \\
\hline $\mathrm{K} 2 \mathrm{O}$ & 0.68 & 2.58 \\
\hline $\mathrm{Na}{ }_{2} \mathrm{O}$ & 0.79 & 0.55 \\
\hline $\mathrm{L} . \mathrm{O} . \mathrm{I}$. & 0.03 & 1.68 \\
\hline
\end{tabular}

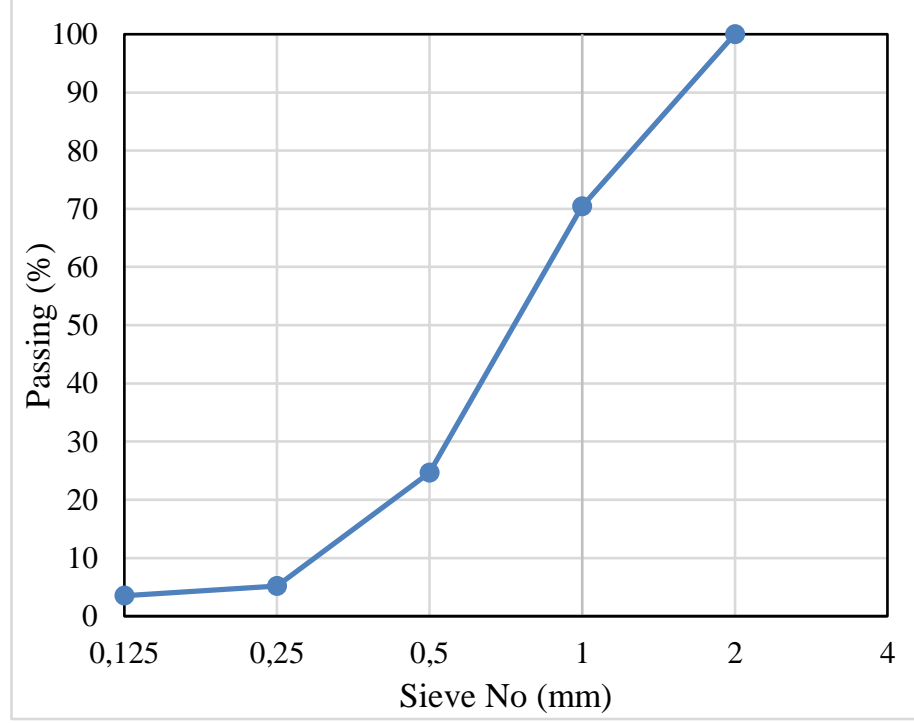

Fig. 2 Sieve analysis of river sand 
Table 2 Properties of sodium hydroxide

\begin{tabular}{|c|c|c|c|c|c|}
\hline $\begin{array}{c}\mathrm{NaOH} \\
(\%)\end{array}$ & $\begin{array}{c}\mathrm{Na}_{2} \mathrm{CO}_{3} \\
(\%)\end{array}$ & $\begin{array}{c}\mathrm{Cl} \\
(\%)\end{array}$ & $\begin{array}{c}\mathbf{S O}_{4} \\
(\%)\end{array}$ & $\begin{array}{c}\mathrm{Al} \\
(\%)\end{array}$ & $\begin{array}{c}\mathbf{F e} \\
(\%)\end{array}$ \\
\hline 99.1 & 0.3 & $\leq$ & $\leq$ & $\leq$ & $\leq$ \\
& & 0.01 & 0.01 & 0.002 & 0.002 \\
\hline
\end{tabular}

Table 3 Properties of sodium silicate

\begin{tabular}{|c|c|c|c|c|}
\hline $\begin{array}{c}\mathbf{N a}_{2} \mathrm{O} \\
(\%)\end{array}$ & $\begin{array}{c}\mathrm{SiO}_{2} \\
(\%)\end{array}$ & $\begin{array}{c}\text { Density } \\
\left(20^{\circ} \mathbf{C}\right) \\
(\mathrm{g} / \mathrm{ml})\end{array}$ & $\begin{array}{c}\mathbf{F e} \\
(\%)\end{array}$ & $\begin{array}{l}\text { Heavy } \\
\text { metals } \\
\text { Pb) }(\%)\end{array}$ \\
\hline 8.2 & 27.0 & 1.360 & $\leq 0.005$ & $\leq 0.005$ \\
\hline
\end{tabular}

Table 4 Properties of used fibers

\begin{tabular}{|c|c|c|c|c|c|}
\hline Type & $\begin{array}{c}\mathbf{L} \\
(\mathbf{m m})\end{array}$ & $\begin{array}{c}\mathbf{D} \\
(\mathbf{m m})\end{array}$ & $\begin{array}{c}\text { Sp. } \\
\text { Gravity } \\
\left(\mathbf{g} / \mathbf{c m}^{\mathbf{3}}\right)\end{array}$ & $\begin{array}{c}\text { Tensile } \\
\text { strength } \\
\mathbf{M P a}\end{array}$ & $\mathbf{L} / \mathbf{D}$ \\
\hline Hook ended & 30 & 0.75 & 7.85 & 2100 & 40 \\
\hline Crimped & 36 & 0.45 & 7.85 & 910 & 80 \\
\hline Twisted & 45 & 0.6 & 0.91 & 850 & 75 \\
\hline elastoplastic & 40 & 0.6 & 0.91 & 750 & 66 \\
\hline Macro nylon & 45 & 0.55 & 1.14 & 500 & 81 \\
\hline
\end{tabular}

Table 5 General mixing notes

\begin{tabular}{|l|l|}
\hline Binder percentage & $\begin{array}{l}50 \% \text { silica fume } \\
+50 \% \text { ggbs }\end{array}$ \\
\hline Ratio of binder to filler & $1: 2.25$ \\
\hline $\begin{array}{l}\text { Ratio of chemical solution to } \\
\text { binder }\end{array}$ & 0.5 \\
\hline Molarity of NaOH (M) & 12 \\
\hline Curing system & Room temp. \\
\hline
\end{tabular}

Table 6 mixing proportions (g)

\begin{tabular}{|c|c|c|c|c|}
\hline $\begin{array}{c}\text { Silica } \\
\text { fume }\end{array}$ & GGBS & Sand & Na2SiO3 & NaOH \\
\hline 225 & 225 & 1012.5 & 150 & 75 \\
\hline
\end{tabular}

a)

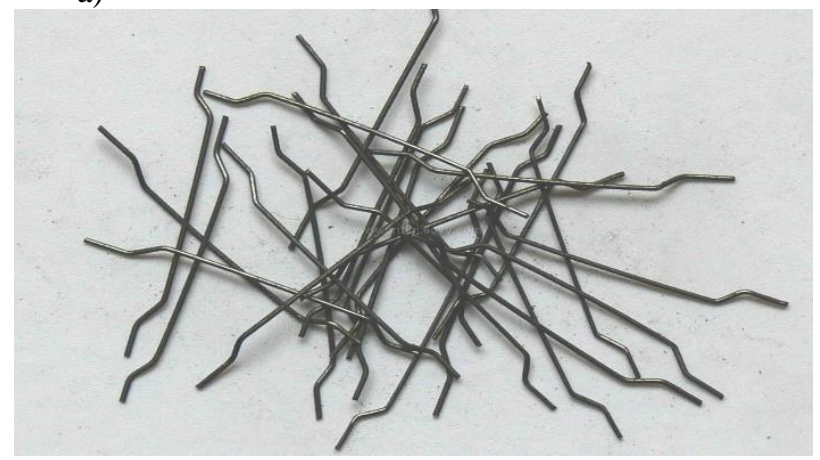

b)

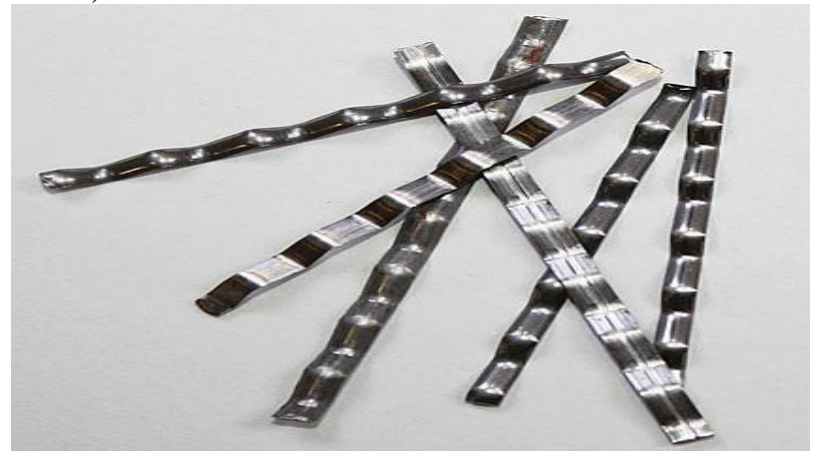

c)

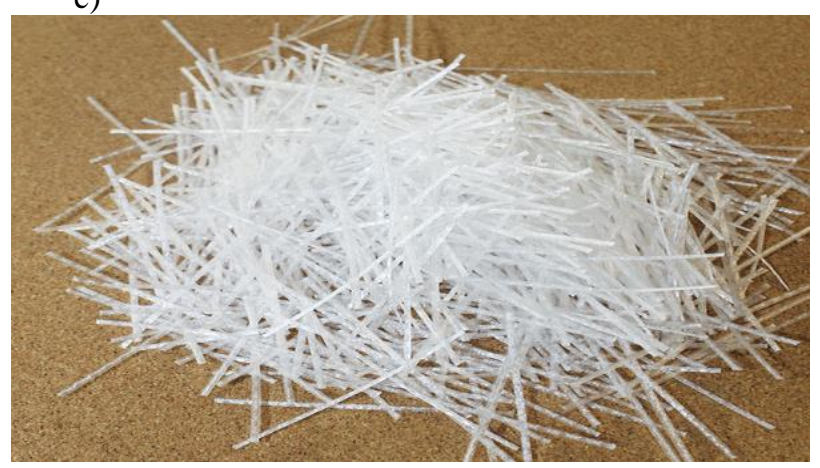

d)

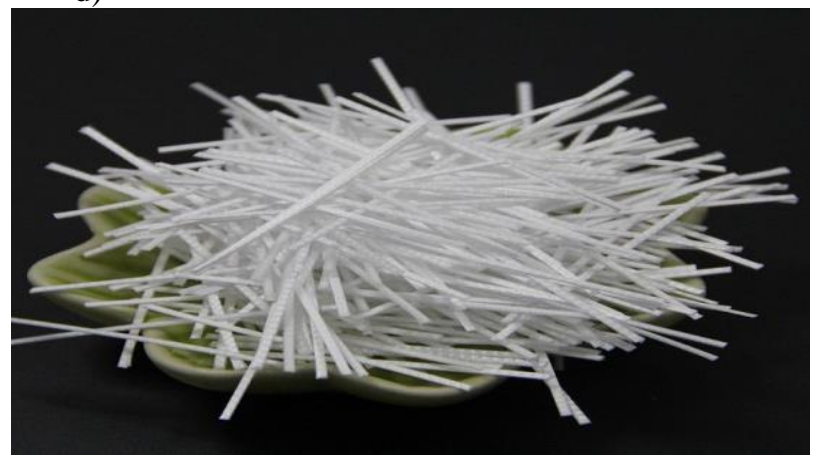

e)

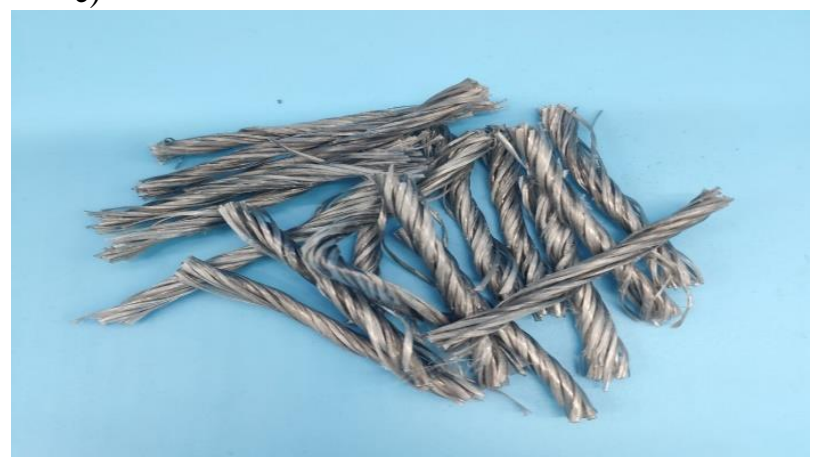

Fig. 3 Samples of a) steel-hook ended b) steel-crimped c) elastoplastic d) macro nylon e) macro twisted fibers 


\subsection{Mix proportions, mixing, and testing methods}

Sodium hydroxide $(12 \mathrm{M})$ was prepared one day before the mixing day and left to cool. On the day of mixing, sodium hydroxide and sodium silicate were mixed to form the chemical activating solution. are given in table 5. Dry materials were first mixed and the chemical solution was added to form Geopolymer paste. Fine sand was then added to the paste to create Geopolymer slurry, the General mixing notes and the mixing proportions are given in tables 5 and 6 , the mixing process is clarified in figure 1 .

The designated molds for compressive and flexural strength tests were cubic molds with $50 \mathrm{~mm}$ side and prismatic molds with dimensions of $(40 \times 40 \times 160) \mathrm{mm}$. the fibers used in this study were put in the mold before the casting process, the mixing process started by pouring Geopolymer slurry into the molds and then the casted specimens were vibrated to eliminate the air bubbles.

Specimens that were designated for elevated temperature tests were put into a high-temperature furnace, the heat increase rate was $1^{\circ} \mathrm{C}$ per minute and the heating process at the desired temperature lasted for one hour. After that, the specimens were allowed to cool to be tested later.

Concerning the tests in this study, compressive and flexural strength tests were conducted according to ASTM C109 [13] and ASTM 348 [14], respectively.

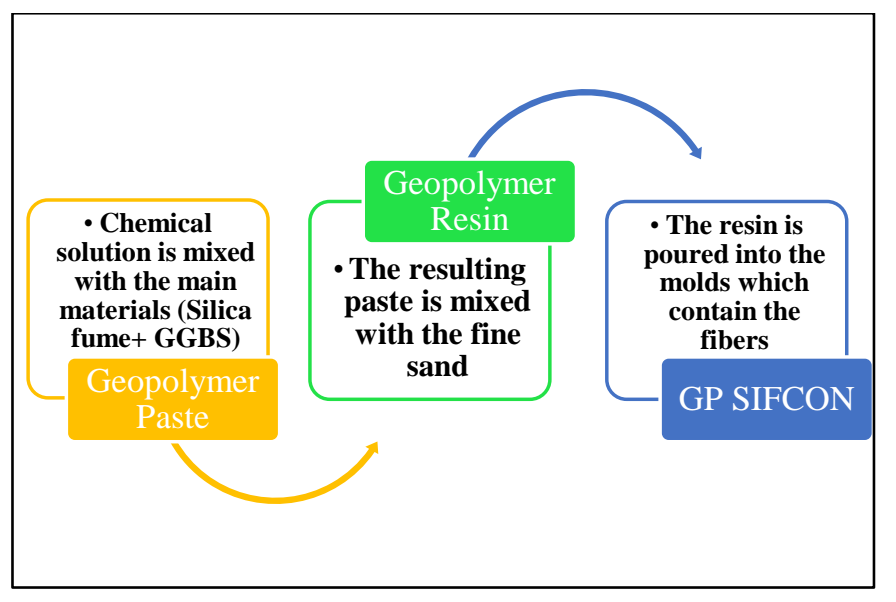

Fig. 4 Mixture steps of the conducted study

\section{Results and Discussion}

As stated in the previous sections, compressive and flexural strength results were determined and listed in Figures 5 and 6. The strength development from 7 days to 28 days was drawn for the fabricated series.

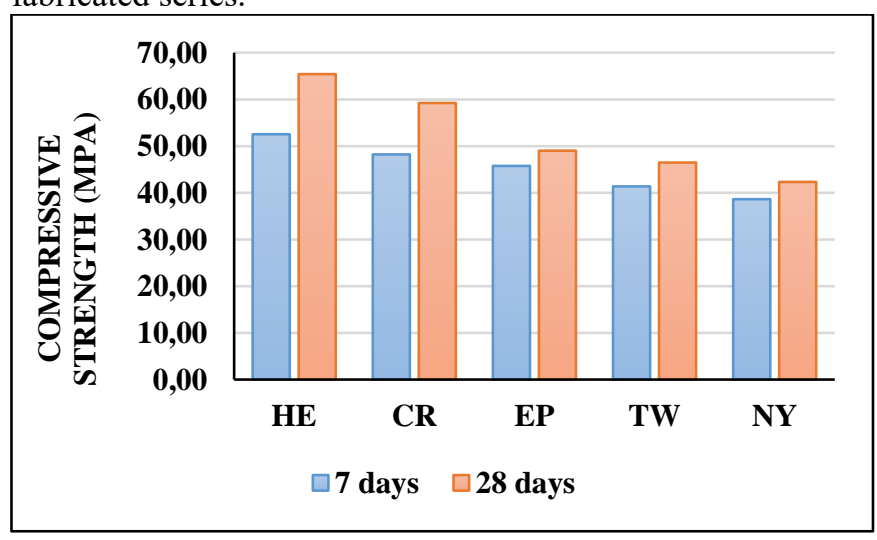

Fig. 5 Compressive strength results of the series

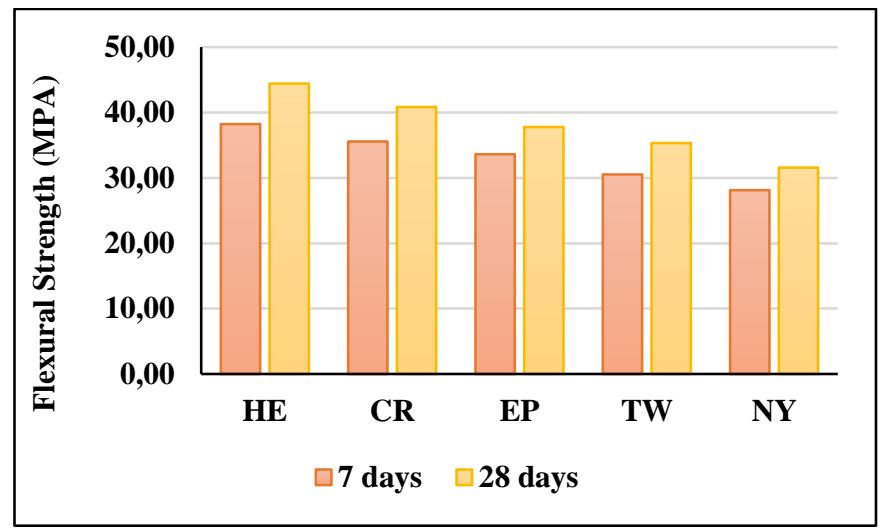

Fig. 6 Flexural strength results of the series

In addition to that, compressive and flexural strength results were listed comparatively with the $28^{\text {th }}$ day's results as shown in figures 5 and 6 .

\subsection{Normal Condition}

In general, the strength results for all series state the fact that the fabricated matrix yielded a development with time. As can be noticed from figure 5, compressive strength for all series developed significantly. The development percentages ranged from $7 \%$ for the EP series to $24 \%$ for the HE series. Series which are reinforced with hook ended and crimped fibers showed the highest increment rates from 7 to 28 days, this can be related to the fact that the interfacial interaction between the geopolymeric matrix and steel fibers is better than that with other fiber types, also, the findings comply with the previous research attempts in this concern $[8,9]$.

Figure 6 shows that the flexural strength development percentages of all series are close to each other, the increment percentages varied from $12 \%$ for EP and NY series to $16 \%$ for HE series. These close percentages can be explained by knowing that the flexural behavior of SIFCON is mainly related to the behavior of the fibers $[15,16]$. HE and $\mathrm{CR}$ series showed better performance when compared to the other series because of the comparable properties of steel-based fibers [8]

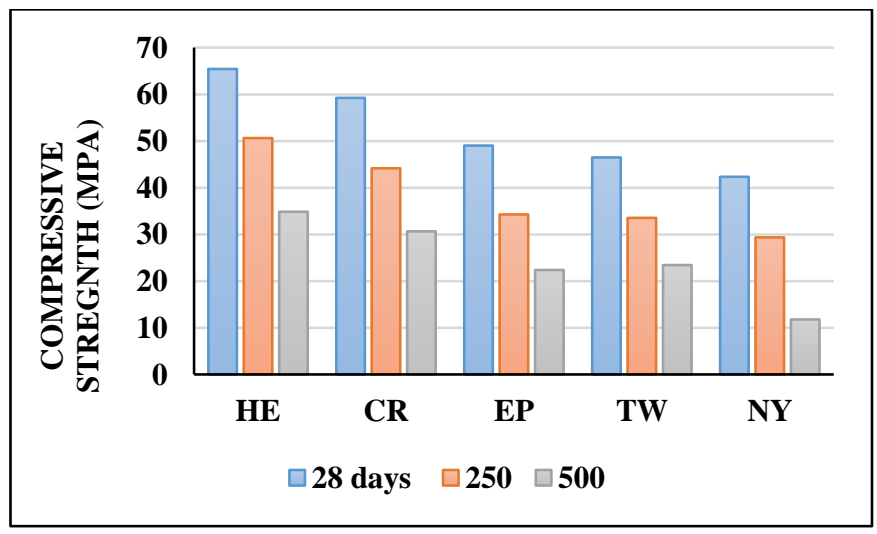

Fig. 7 Compressive strength results after elevated temperature tests 


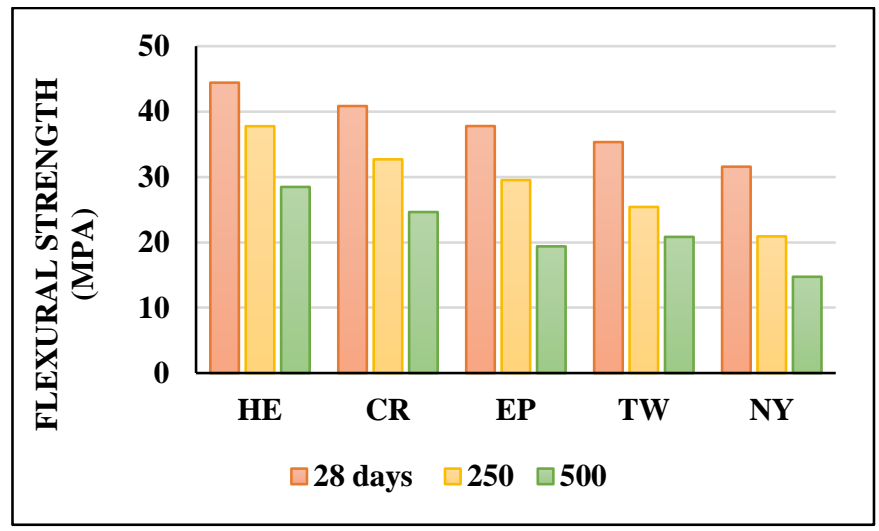

Fig. 8 Flexural strength results after elevated temperature tests

\subsection{High Temperature Test}

Concerning the elevated temperature tests, the compressive strength results which are given in figure 7 show that the decrement percentages in all series range between $22 \%$ for $\mathrm{HE}$ series and approximately $30 \%$ for NY and EP series at $250^{\circ} \mathrm{C}$ and between $46 \%$ for $\mathrm{HE}$ series and $72 \%$ for $\mathrm{NY}$ series at $500^{\circ} \mathrm{C}$.

Flexural strength which is given in figure 8 shows that loss percentages were between $14 \%$ (HE series) and $33 \%$ at $250^{\circ} \mathrm{C}$, and between $35 \%$ (HE series) and $53 \%$ (NY series) at $500^{\circ} \mathrm{C}$.

In general, the results show that specimens with steel fibers yielded better results in comparison to specimens reinforced with other fibers, this performance is related to the good interfacial bonding between fibers and geopolymeric matrix and to the comparable melting points of steel fibers in compliance with the findings [16].

On the other hand, the results of the specimens with macro synthetic twisted fibers revealed the fact that using these fibers is feasible in SIFCON applications, and with geopolymeric matrix, the findings are in line with the previous investigations in the field [17].

Although they showed weak performance when compared to steel and polyamide fibers, elastoplastic and nylon fibers could be used in this application as potential fiber for SIFCON.

\section{Conclusion}

This experimental investigation aimed to study the usage of different fibers with the geopolymeric matrix to fabricate SIFCON specimens, strength properties, namely compressive and flexural strengths, were determined in normal condition and after being subjected to elevated temperatures, the main conclusions can be drawn out from the results:

1. Generally, fabricating SIFCON with geopolymeric matrix is possible with slag-silica fume as the main precursors.

2. Specimens that were reinforced with steel fibers (hook ended and crimped) showed better results in both conditions when compared to other fibers because of the good fiber-matrix bonding degree as well as the comparable properties of fibers.
3. Using macro synthetic twisted fibers in SIFCON applications was found to be possible since these fibers showed an acceptable performance in the conducted tests.

4. In comparison to other fibers, elastoplastic and nylon fibers showed weaker strength results under the influence of elevated temperatures due to the low melting points of these fibers.

\section{References}

[1] Yang, Keun-Hyeok, Jin-Kyu Song, and Keum-Il Song. "Assessment of $\mathrm{CO} 2$ reduction of alkali-activated concrete." Journal of Cleaner Production 39 (2013): 265272.

[2] Shi, Caijun, A. Fernández Jiménez, and Angel Palomo. "New cements for the 21st century: The pursuit of an alternative to Portland cement." Cement and concrete research 41, no. 7 (2011): 750-763.

[3] Hasanbeigi, Ali, Christoph Menke, and Lynn Price. "The $\mathrm{CO} 2$ abatement cost curve for the Thailand cement industry." Journal of Cleaner Production 18, no. 15 (2010): 1509-1518.

[4] Davidovits, Joseph. "Global warming impact on the cement and aggregates industries." World resource review 6 , no. 2 (1994): 263-278.

[5] Davidovits, Joseph. "Geopolymers and geopolymeric materials." Journal of thermal analysis 35, no. 2 (1989): 429-441.

[6] Islam, Azizul, U. Johnson Alengaram, Mohd Zamin Jumaat, Nurasyiqin Binti Ghazali, Sumiani Yusoff, and Iftekhair Ibnul Bashar. "Influence of steel fibers on the mechanical properties and impact resistance of lightweight geopolymer concrete." Construction and Building Materials 152 (2017): 964-977.

[7] Ganesan, N., Ruby Abraham, and S. Deepa Raj. "Durability characteristics of steel fibre reinforced geopolymer concrete." Construction and Building Materials 93 (2015): 471-476.

[8] Bhutta, Aamer, Paulo HR Borges, Cristina Zanotti, Mohammed Farooq, and Nemkumar Banthia. "Flexural behavior of geopolymer composites reinforced with steel and polypropylene macro fibers." Cement and Concrete Composites 80 (2017): 31-40.

[9] Aygörmez, Yurdakul, Mukhallad M. Al-mashhadani, and Orhan Canpolat. "High-temperature effects on white cement-based slurry infiltrated fiber concrete with metakaolin and fly ash additive." Revista de la construcción 19, no. 2 (2020): 324-333.

[10] Naaman, Antoine E., and Joseph R. Homrich. "Tensile stress-strain properties of SIFCON." Materials Journal 86, no. 3 (1989): 244-251.

[11] Kar, David R. Lan. "Properties, applications: Slurry infiltrated fiber concrete (SIFCON)." Concrete International 6, no. 12 (1984): 44-47.

[12] En, British Standard. "Methods of testing cement-Part 1: Determination of strength." European Committee for Standardization: Brussels, Belgium 169 (2005): 36.

[13] ASTM, C. "Standard test method for compressive strength of hydraulic cement mortars." ASTM International (2008). 
[14] ASTM, ASTM. "C348-14 Standard Test Method for Flexural Strength of Hydraulic-Cement Mortars, ASTM Int." West Conshohocken.

[15] Tuyan, Murat, and Halit Yazıcı. "Pull-out behavior of single steel fiber from SIFCON matrix." Construction and Building Materials 35 (2012): 571-577.

[16] Beglarigale, Ahsanollah, Çağlar Yalçınkaya, Hüseyin Yiğiter, and Halit Yazıcı. "Flexural performance of SIFCON composites subjected to high temperature." Construction and Building Materials 104 (2016): 99-108.

[17] Mohod, Milind V. "Performance of polypropylene fibre reinforced concrete." IOSR Journal of Mechanical and Civil Engineering 12, no. 1 (2015): 28-36. 